anaesthesia and with liberal replacement of the age of 35 . On the other hand, as the blood.-We are, etc.,

T. C. THORNE

Department of Anaesthesia, General Hospital,

J. AlFRED LEE

\section{Death during Dental Anaesthesia}

SIR,-With reference to your medicolegal report (2 February, p. 207) entitled "Death during Dental Anaesthesia" I wish to make the following comments.

In evidence Mr. Alan Williams said regarding intravenous methohexitone, that "he had been instructed in its use at a course run by the Society for the Advancement of Anaesthesia in Dentistry." From this it might be inferred that the S.A.A.D. claimed to turn out trained anaesthetists after three days' tuition. This is far from the case, and I quote from my own lecture on the course: "If you expect to go away after three days, fully trained and fit to launch yourselves on your unsuspecting patients, think again please. In this short time, we can only give you the rudiments of the subject for you to build on by further study. We lay great stress on the complications that can occur, and tell you how to treat them, and mors importantly, we try to show how to conduct your practice so that you prevent complications occurring. We lay down strict basic rules of safe anaesthetic practice and insist that these are followed completely in every case."

Regarding Mr. Williams's "six breaths of nitrous oxide"; during the course, in lectures and demonstrations, he was repeatedly warned of the dangers of anoxia. This point receives frequent mention in the S.A.A.D. Manual, 3rd edition, which he was advised to study. The following extracts are appropriate to the case. P. 2, para. 1.- "The rules of safety are clearly defined. Until they can be adhered to, the method must not be attempted." P. 9, Recommendations, no. 2"Oxygen restriction below $20 \%$ is never needed and should never be tolerated. Any technique . . . in which there may be a temptation to restrict oxygen ... should be carefully avoided." P. 16, Criteria, para. 2"Oxygen restriction neither follows the administration of methohexitone nor is it necessary in any of the techniques employing it." P. 31, para. 3-"Many complications can occur from abuse of the method. At all times the fundamental principles of safety must be striotly followed." $P$. 38, Care and Control, para. 4.-"The dangers of anoxia must be avoided by never reducing the oxygen below 20\%. P. 40, Causes of Anoxia, no. 2.-"Oxygen restriction during inhalation anaesthesia." P. 39, Causes of Hypotension, (b)_"Anoxia."-I am, etc.,

DONALD BLATCHLEY President,
Society for the Advancement of
Anaesthesia in Dentistry

London $\mathbf{W} .1$

\section{Vaginal Cytology}

SIR,-In reply to Mr. S. A. Way's letter (2 February, p. 201) it should be made clear that the Department of Health and Social Security has at no time stated that cervical cytological examination is unnecessary below
Registrar General's figures show, it is in those women aged 45 and over that the incidence of invasive cervical carcinoma is highest, and in situ carcinoma tends to precede the invasive lesion by 10 years.

The most urgent matter therefore has been to aim at comprehensive screening of women aged 35 and over, and to encourage this a fee for service is paid to general practitioners screening such women. This priority group has recently been extended to include selected higher-risk women below the age of 35 . That general practitioners and others realize that younger women may be at risk is clear from the national figures, which show that about one-half of the two million smears taken annually in England and Wales come from women below the age of 35.-I am, etc.,

$$
\begin{array}{r}
\text { J. C. MCCluRe Browne } \\
\text { Chairman, } \\
\text { D.H.S.S. Committee on Gynaecological Cytology }
\end{array}
$$

Inst:tute of Obstetrics and Gynaecology,

Hammersmith Hospital,

\section{Gamekeeper's Thumb on the Ski Slopes}

SIR, - With reference to your leading article on this subject (9 February, p. 213), in addition to the mechanism described this injury appears to be more common on artificial training ski slopes, where the run is made of nylon mesh. In the event of a fall the thumb gets caught in the nylon mesh, and with the momentum of the body forced abduction ruptures the ulnar collateral ligament of the metacarpophlangeal joint of the thumb. - I am, etc.,

\section{B. P. KRISHNAMURTHY}

Bath \& Wessex Orthopaedic Hospital, Bath

\section{British Academy of Psychopharmacology}

SIR,-For many years the United Kingdom has lagged behind other countries in having no specific organization dedicated to psychopharmacology. Thus a number of other countries have established their own national organizations that are affiliated to the Collegium Internationale NeuroPsychopharmacologicum (C.I.N.P.), one of the best known of these being the American College of Neuro-Psychopharmacology.

In view of the considerable contributions made by our country to psychopharmacology it appears to us that the present situation is anomalous and that the time has come to establish a national organization in Britain. To avoid confusion with the royal colleges we propose that this organization be called "The British Academy of Psychopharmacology."

We believe that there is a particular need to focus attention on the importance of drug treatment in psychiatry in the eyes of both the young clinician and the research scientist. Therefore the objects of the academy will be to further research in psychopharmacology, both clinical and experimental, and to improve the quality and standards of psychotropic drug evaluation. This can be accomplished by means of the spoken and written word through the media of meetings, study groups, and publications.
We propose to call a meeting in the near future of all those members of the profession who may have an active inrerest in psychopharmacology for the purpose of determining the constitution of the academy, to elect officers, and to consider the academy's policy, particularly in relation to the pharmaceutical industry. To this end we have drafted some suggestions and would be pleased to forward these to any interested member of the profession. We would also like to receive suggestions and comments concerning the establishment of the academy, and invite those interested to communicate with any one of the undersigned.-We are, etc.,

SYDNEY BRANDON University Department of Psychiatry, Manchester

West Park Hospital,

ALEC COPPEN

Epsom, Surrey

University Department of Psychiatry,

Max Hamilton

Leeds

MICHAEL HOLDEN

Middlewood and United Sheffield Hospitals,

Sheffield

ANTHONY HORDERN

Department of Psychiatry,

King's College

All Saints Hospital,

NORMAN IMLAH

Birmingham

University Department of Psychiatry,

ALEX JENNER

Middlewood Hospital,

West Park Hospital,

David Shaw

Epsom, Surrey

General Practitioner Research Group,

David Wheatley

Twickenham

\section{Home Graduates Only}

SIR,-I heartily agree with Dr. T. K. Ghosh (16 February, p. 290).

I am a British subject now, but I am an Indian. I came to England in 1956 and have enjoyed every moment of my stay in this wonderful country. I was well aware of various attitudes in my medical colleagues but found that all these attitudes stemmed from a lack of communication by both parties concerned. When one appreciates British humour and their in-built sense of justice one soon realizes that the English as taught to us is vastly different from regional spoken English. When one masters this, one is no longer an outsider, no more so than a British missionary in, say, India can master the local vernacular and the local humour and still be an outsider. We are all colleagues, and if we would only "specialize" in the local English at the "local" (if you will pardon the pun), would not things be easier?-I am, etc.,

H. A. LesiIE

London N.2

\section{Vitamin A, Pregnancy, and Oral} Contraceptives

SIR,-Mrs. Jennifer Wild and her colleagues (12 January, p. 57) sought to show that oral contraceptives increase serum vitamin A levels and investigated the hypothesis that there is an increased teratogenic risk for mothers who become pregnant at such a time. However, their conclusions were 